\title{
Crime of Makar and Its Enforcement in Post- Reform Indonesia
}

\section{Eman Sulaeman}

Walisongo State Islamic University, Semarang. Indonesia

e-mail: eman_apsi@yahoo.com

\begin{abstract}
Di era reformasi yang ditandai dengan adanya kemerdekaan berfikir dan berpendapat, posisi rumusan tidak pidana makar dalam Kitab UndangUndang Hukum Pidana (KUHP) sangat dilematis. Di satu sisi, rumusan tindak pidana makar dibutuhkan guna menjaga kedaulatan negara. Namun di sisi lain, kehadirannya yang tidak terdefinisikan dengan baik mengancam kemerdekaan hak konstitusional warga negara. KUHP tidak memberikan definisi yang jelas tentang apa yang dimaksud dengan tindak pidana makar beserta unsur-unsurnya.

Tulisan ini akan menganalisis bagaimana formulasi tindak pidana makar di dalam KUHP, penegakannya di Indonesia pasca reformasi, serta formulasinya dalam Rancangan Undang-Undang (RUU) KUHP ke depan. Metode penelitian yang digunakan adalah (library riset) melalui pendekatan yuridis-normatif. Hasil penelitian ini, bahwa bahwa rumusan tindak pidana makar yang diatur dalam Pasal 104, 106, 107, dan 108 KUHP tidak mendefinisikan apa yang dimaksud dengan makar itu sendiri, serta tidak memberikan parameter yang jelas terhadap unsur-unsurnya. Dengan demikian diperlukan upaya pembaharuan hukum pidana guna menaggulangi kejahatan tindak pidana makar yang efektif dan sesuai dengan prinsip-prinsip negara hukum dan demokrasi dalam Rancangan Undang-Undang (RUU) KUHP.
\end{abstract}

Keywords: Tindak pidana; makar; pembaharuan hukum pidana 
In the era of reforms characterized by freedom of thought and opinion, the position of makar crime formulation in the criminal law book (KUHP) is very dilemmatic. Its Formulation is needed to maintain state sovereignty. However, its presence has not well defined yet.. So, it threatens the independence of Makar crime and its elements. This research will analyze the formulation of Makar crime in the Criminal law book (KUHP), its enforcement in Indonesia post-reforms, and its draft formulation in the Criminal law book (KUHP). Library research method through juridicalnormative was used in this research. The result shows that the formulation of Makar crime which was set forth in Article 104, 106, 107, and 108 of the Criminal law book (KUHP) still has not define Makar and its parameters to the elements. Therefore, it is necessary to reform the criminal law effectively in accordance with the principles of law and democratic state in the Draft Law (RUU) of the Criminal law book (KUHP) in order to overcome Makar crime

Keywords: Crime; treason; renewal of criminal law

\section{Introduction}

In the opening of the 1945 Constitution, the fourth paragraph contains the national purpose. One of which is to protect the Indonesian nation. (Government of the Republic of Indonesia 1945: 18). This purpose implies that the state or government has responsibility for the defense and security of the Unitary State of the Republic of Indonesia (NKRI) from all threats, both from within and outside the country such as rebellion, Makar, terrorism, and embracing communism. Based on this, the concept of state security emerged as a preventive and repressive means (Government of the Republic of Indonesia 2008: 108) for all forms of efforts that could facilitate and support the stability (Agustin 2013: 344).

In the new order, this concept was used as a tool for the authorities to silence and get rid of those who carried out demonstrations that were critical of government policies that were not in favor of the community. As an independent nation, Indonesia has several concepts of state security in number of legal products such as the Criminal law book (KUHP), the Criminal law book (KUHP) Bill, the Decree of the MPR, the Subversion 
Law, the Law on National Defense, and others (Agustian tt: 345). Thus, Law guarantees the security and integrity of the Unitary Republic of Indonesia as a preventive measure of crime against the state. The term 'Makar" has been warmly discussed and often adorned newspaper headlines, both print and electronic media, along with a heated political atmosphere of Jakarta regional elections and the blasphemy case of Basuki Tjahaja Purnama that led to demonstrations of 212 at Monas Jakarta. On December 12, 2016, the Jakarta Metropolitan Police arrested 11 activists of different locations who allegedly committed Makar crime before the 2 December 2016 action. Seven of which were alleged under Article 107 of the KHUP junto 110 Criminal law book (KUHP) 110. They are Kivlan Zein, Adityawarman, Ratna Serumpet, Firza Husein, Eko Suryo Santjojo, Alvin Indra, and Rahmawati Sukarno Putri. While the other 3 were charged with Article ITE Law 107, they are Sry Bintang Pamungkas, Jamran, and Rizal (Republika 2 December 2016).

In addition, this term has been popular since the National Police Chief and Commander of the Armed Forces has stated that there would be the Makar plans from the 212 demonstration which provoked the occupation of the DPR building, then urged the MPR Special Session to revoke its mandate from President Joko Widodo. The National Police Chief and General TNI's statements were certainly with evidence (Lampung Pos 27 November 2016). In addition, there were also public reports that complain incitement to bring down a legitimate government. One of the reports came from Laskar Jokowi's attorney, Ridwan Hanafi. He reported this case to the Jaya Regional Police with some proofs of video, photos and witnesses registered No. LP / 5735 / XI / 2016 / PM / DirsReskrimum 21 December 2016. In this case, the alleged perpetrator was Sri Bintang Pamungkas (Metrotv 22 November 2016). era, there were more arrests from PrabowoSandi supporters who were suspected of committing criminal offenses as an excess of chaos in the 2019 presidential election. Again, this case was not handled completely. Before Jokowi's era, legal experts have not discussed the Makar yet. Even they stated that the article in the Criminal law book (KUHP) is considered as a dead article. In fact, the term Makar is found in the Criminal law book (KUHP). However, there is no clear definition about it (Widyati 2016). In the Criminal law book (KUHP), Makar is mentioned in 
articles $87,104,107,108$, and 140 , with no mention of what is meant by the Criminal law book (KUHP). Some articles are seen as follows:

Article 87: It is said that there is Makar to commit an act if the intention has been seen from the beginning of execution as referred to in Article 53 .

Article 53: Trying to commit Makar will be convicted if the intention to do so has appeared from the beginning of execution, and the incompletion of the act is solely due to his will.

Article 104: Makar intended to kill President or Vice-President or to deprive from their independence or to render them incapable to rule, will be sentenced to death or imprisoned along lifetime or 20 years-temporary prison. (Moeljatno 1996: 83, 57 and 361).

In Article 104, there are two elements, namely subjective and objective element. The subjective element is inherent within the offender's self or everything emerges from his heart (Marpaung 1991: 9). Intention as the subjective element has been explained in Articles 53 and 87. This act is considered Makar if the intention of the crime-maker has been proven since the commencement of the act (Moeljatno 1996: 88). On the other hand, the objective element is considered to do with the circumstances, namely in circumstances where the actions of the perpetrator must be done (Marpaung 1991: 9). The objective elements concerning Article 104 are as follows:

\section{a. Aanslag}

The word aanslag is mostly interpreted as Makar. The law does not provide an explanation of what is meant aanslag. In the Dutch language as quoted by P.A.F Lamitang (1987: 5), among other things is interpreted as an attack with no good intentions. The purpose of the attack is to overthrow the government and destroy the government system in an illegal way.

\section{b. Kill the president or vice president}

To kill means to take lives. Since this element is located behind the element with a purpose, it should be clear that the perpetrators want the loss of the life of the president or vice president. In the element of loss of life this means that there is an element of intent and intent is closely related to intention. Prof. NoyonLangemejjer as quoted by P.A.F Lamitang (1987: 25) said that the Makar must be 
carried out with a view to taking away the lives of the president or vice president or making them incapable of governing. That means that people who commit Makar, must want to do something that can be qualified as an act of taking lives.

c. Depriving the president or vice president of independence

This objective element lies behind the element with the intention also, then it is clear that the perpetrators want to be deprived of the independence of the president or vice president, and he must know that the independence he seized is the independence of the president or vice president, then the object is the head of state. This action cannot be included in article 104 if the culprit who commits this action does not know that the president is being harmed, because such acts include culpa or negligence.

In addition to article 104 of the Criminal law book (KUHP), there are articles that describe criminal offenses, namely articles 107 and 108. This article is closer to rebellion because this article leads to the overthrow of the government. Based on this, the term Makar that has no legal certainty related to its definition has been a problem in criminal law since the first time that the word was used in Indonesia. The Executive Director of the Criminal for Justice Reform (ICJR) Institute, Supriyadi Widodo, considers that the Criminal law book (KUHP) does not provide an exact definition of the term Makar that was first used in article 87, which also provides unclear objectives and formulations in subsequent Articles, namely Article 104 106, 107, 139a, 139b, and 140 of the Criminal law book (KUHP). In line with that, Joko Prakoso also stated that the word makar is a translation of the word Aanslag which means attack. According to him, the Criminal law book (KUHP) does not provide a definitive definition of the word Aanslag, but only provides an authentic or special interpretation through Article 87 of the Criminal law book (KUHP). Driving the opinions of Noyon and Prof. Langemeijer, Supriyardi added that most acts of Aanslag were acts of violence or at least were attempts to commit acts of violence. 
For the unclear interpretation, the article Makarable crime is misused by the authorities. The Makar article is considered as a rubber article, but normatively this article is still valid, so the interpretation of the article becomes very broad. Therefore, the authorities can act subjectively in upholding this article and tend to use it to silence political opponents who intend to be critical of their policies. This we can see ahead of the Islamic defense action on 12 December 2016 ago. Through the Metro Jaya Regional Police, the National Police issued a notice Mak / 04 / XI / 2016 on Submitting Public Opinion following the alleged use of the Islamic defense period to occupy the Parliament building and plotting to overthrow the legitimate government. In this regard, the article on Makar crimes needs to be reviewed to clarify the objectives and formulations desired by the law in order to maintain the integrity of the nation and to create certainty of boundaries between critical and Makar efforts, so that all citizens can continue to exercise their rights as citizens an independent and the government and law enforcement can still carry out their duties to maintain the integrity of the country.

\section{Criminal Policy in Makar Crime Formulation}

Crime is part of a crime. In this case, what is directly related to the legal order and process of nation and state is a crime in a crime especially a crime against the state or state security. Sociologically it is called a political crime. The word politics comes from the Greek 'politia' which means everything that related to the state or all actions, policies, tactics about governing a country. Crimes against the state security include criminal acts that are contrary to the rule of law and are directed against the state. The crime is committed by citizens by making the system of power or government in a country as its object or target.

One of the criminal acts aimed at the state is Makar (Trahjurendra tt: 3). Crimes of Makar are formulated in the Criminal law book (KUHP), including the following:

1. Article of Criminal Acts in the Criminal law book (KUHP) 
Makar comes from the Dutch "Aansleg" which is according to the literal meaning is an attack. The term Aansleg is also contained in the Criminal law book (KUHP) namely in articles 87, 104, 105, 106, 107, 130, 139a, 139b, and 140 (articles 105 and 130 are considered no longer valid based on Law Number 1 of 1946, Article VIII, item 3), but the Makar contained in articles 139a, 139b, and 140 of the Criminal law book (KUHP) does not enter the chapter on crimes against state security, but includes crimes against friendly countries, friendly heads of countries and their representatives (Chazami 2002: 7). Understanding the term 'Makar' can be described by quoting the original editorial from article 107 paragraph 1 of the Criminal law book (KUHP) which reads:

"De aansleg, ondornomen met het oogmerk om omventelingteweeg te brengen, wordtgestraft met gevangenisstraft van ten hoogstevifitienjaren" (Prakoso 1986: 15)."

Engelbrecth translated the article with; "Makar committed with the intent to undermine the government, punishable by imprisonment for fifteen years" (Prakoso 1986: 15). Moeljatno (1986: 15) gives the following translation: 'Makar with the intention of writing down the government, threatened with a maximum imprisonment of fifteen years'. From Engelbrecht and Moeljatno's translation it can be seen that translating the word 'Aansleg' with the word Makar In this case, Wirjono Prodjodikoro uses the word makar as the translation of the word 'Aansleg', which according to him means attack (Prodjodikoro 2008: 187).

Regarding the term Makar in the Criminal law book (KUHP) itself begins specific interpretation can be found in article 87 of the Criminal law book (KUHP), which reads:

'It is said that there is a plot to commit an act, if the intention for that has been evident from the beginning of the implementation as referred to in article 53 of the Criminal law book (KUHP). (Prakoso, 1986: 10).

Thus, in fact Makar itself is a special definition relating to the requirements that exist in terms of being able to be convicted of an 
attempted trial which is translated in Article 53 of the Criminal law book (KUHP) paragraph 1, namely :

'Trying to commit a crime is criminalized, if the intention for that has been evident from the beginning of the implementation, and the completion of the execution is not solely due to his own free will '(Chazami 2002: 8).

Based on the article above, it can be concluded that the most important elements of Makar to do an action are as follows;

a. Intention

b. Start of Implementation

c. The implementation was not finished not solely of his own free will

If we are connecting the article 87 of Criminal law book (KUHP) concerning Makar and the article 53 of Criminal law book (KUHP) concerning the beginning of the implementation, then it is clear that the Makar article is not the name or qualification of a crime that we often hear, but a form of certain behavior that meets certain elements or conditions. In the Criminal law book (KUHP), specifically, Makar is regulated in the articles as follows:

a. Crimes of Makar with the intent to eliminate the life or independence of the president or vice president are regulated in article 104 of the Criminal law book (KUHP) which in Dutch reads:

"De aansleg undernomen met het oogmerk om den President of den Vice-President van het leven of de vrijheid te rooven of tot regeeren ongeschhikt te meken, wordt gestrft met de doodstraf of levenlange gevange nistraft of tojdelijke van ten goongste twintig jaren".

Meaning: Makar that committed with the intention of killing the President or Vice President, or with the intention of depriving them of their independence or rendering them incapable of governing, threatened with capital punishment or life imprisonment or imprisonment for a specified period of time of at most twenty years (Moeljatno, 1996 : 43). 
b. Crime of Makar with the intention of bringing the whole or part of the territory of a country under the foreign authority or to separate a part of the state territory is regulated in article 106 of the Criminal law book (KUHP). Criminal offense committed with the intention to bring the whole or part of the territory of a country under the foreign authority or to separate a part of the territory of the country, by forming a law has been regulated in article 106 of the Criminal law book (KUHP) whose formulation in Dutch reads :

De aanslag ondernomen met het oogmerk om het grongehied van den staat geheel of gedeeltelijik order vreemde beerschsppij te brengen of om een deel daarvan af te scheiden, wordt gestraft met levenslange gevengenistraft of tijdelijke vn ten hoongste twintig jaren, (Lamintang 1987: 39)

Meaning: Makar committed with the purpose to bring the whole or part of the territory of a country under the foreign authority or to separate a part of the state, be sentenced to life imprisonment or with a temporary prison at least twenty years (Moeljatno 1996: 43).

c. Crimes of Makar with the intention of bringing down the government (article 107 of the Indonesian Criminal law book (KUHP)). The Makar criminal act carried out with the intention to overthrow the government by the legislators has been regulated in article 107 of the Criminal law book (KUHP), the formulation in Dutch reads as follows:

1. De aanslag ondernomen met het oogmerk teweeg te brengen, wordt gestraft met gevangenistraft van ten gongste-vijftien jaren, (Makar that committed with the intention of overthrowing the government, sentenced to prison for fifteen years). 
2. Leiders en aanleggers van en aanslag als in het eerste lid bedoeld, worden gestraft met levebslange gevangenistraft of tijdelijke van ten hoongste twintig jaren, (Leaders and planners of Makar, as in the paragraph 1, were sentenced to life imprisonment or twenty years in prison) (Lamintang 1987: 49).

The formula of Makar criminal article in the Criminal law book (KUHP) does not stand alone. It is need the formulation from the other articles to be able to impose a crime on someone who has suspected of committing criminal offenses which is contained in articles 104, 106, and 107. As for those relating to Articles 104, 106 and 107 of the Indonesian Criminal law book (KUHP), as stated by Prakoso (1986: 48-56) is as follows :

a. Related to Articles 104, 106 and 107 of the Indonesian Criminal law book (KUHP) are:

1. Article 4 paragraph 1 of the Criminal law book (KUHP)

Criminal rules in Indonesian law is apply to anyone outside Indonesia that is committing, (1) one of the crimes of articles 104,106, 107, 108, 110, 111 bus 1st, 127th and 131st. The article is an embodiment from the principle of protection (the passive national principle). According to the principle, the rules of Indonesian criminal law is applying to criminal acts that attack the interests of the country's law whether committed by Indonesian citizens or not, which are carried out outside Indonesia. These crimes can be divided into 5 categories:

a) Crimes against the state security and the dignity of the president (article 4 sub 1);

b) Crimes against the material or trademarks issued by the Indonesian government (article 4 sub 2);

c) Falsification of debt documents and debt certificates at the expense of falsified Indonesia (article 4 sub 3); 
d) Crimes listed in title XVIII book II committed by Indonesian civil servants outside Indonesia (article 7);

e) Shipping crimes listed in title XXIX book II, shipping violations and also criminal offenses listed in the regulations on sea and passport documents in Indonesia and in the 1972 ship ordinance committed by Indonesian captain and passenger of shipping equipment. there are outside Indonesia whether they are on the boat or outside the ship (article 8).

2. Article 110 of the Criminal law book (KUHP)

a. Conspiracy to commit such crimes article 104-108, is threatened with a maximum punishment of six years.

b. The criminal law book (KUHP) also applies to people who are intend to prepare or expedite the crime, articles 104-108 of the Criminal law book (KUHP). (1) trying to instigate other people to commit the crimes, or effort to provide assistance when doing or giving opportunity or information to commit the crimes; (2) trying to get an opportunity or information to commit a crime for oneself or another person; (3) has a stock of goods which are known to be useful for committing crimes; (4) prepare or have a plan to carry out crimes intended to be notified by others; (5) trying to prevent, obstruct or thwart actions taken by the government to suppress or prevent the commission of crime.

c. Articles referred in paragraph 23 can be confiscated.

d. No criminal shall be found who turns out that the intention is only to prepare or facilitate changes in the state administration in the general sense. 
e. If any of the error referred in paragraph 1 to 2 of this article, a crime really occurs, the penalty can be doubled.

(1) The deeds of consensus in article 110 paragraph 1 of the Criminal law book (KUHP) are prohibited acts. This act is in accordance with Article 88 of the Indonesian Criminal law book (KUHP), which is an act of consensus or agreement to commit a crime. The crime itself has not yet been seen, only preparations or deeds are still planned.

(2) The type of act in paragraph 2 apparently does not yet appear to lead the desired crime.

(3) The acts in paragraph 2 apparently cannot be punished if carried out with a view to preparing or facilitating in planning or developing constitutionality in the general sense.

3. Article 128 of the Criminal law book (KUHP)

In the case of criminalization in the aforementioned crime article 104 may also be imposed with the criminal revocation of the rights mentioned in article 35 paragraph 1-5. (1) Right to hold office in general or certain position; (2) Right to enter the armed forces; (3) The right to vote and be elected in an election held based on general rules; (4) The right to be an advisor or manager according to law, the right to be a guardian, supervisor or guardian supervisor, or people who are not their own children; (5) The right to exercise the power of the father, to carry out representation or support for his own children.

In the case of criminal offenses for the aforementioned crimes, articles 106, 108, 110, 125 may also be imposed with criminal revocation of the said rights, articles 35 to 1-3. (1) The right to hold office in general; (2) Right to enter the 
armed forces; (3) The right to vote and be elected in an election held based on general rules.

4. Article 131 of the Criminal law book (KUHP)

"Every act of attacking against the President or Vice President who is not included in the more severe criminal provisions, is threatened with a maximum imprisonment of 8 years".

This attack can be interpreted the same as 'depriving independence' as stipulated in article 104 of the Criminal law book (KUHP). This attack must be aimed at the body rather than a good name, if it is aimed at the good name then the act was threatened based on article 134 of the Criminal law book (KUHP).

5. Article 140 of the Criminal law book (KUHP)

a. Makar against the life or independence of the king, who rules, or other heads of friendly countries, are liable to a maximum of fifteen years in prison;

b. If a Makar of life is planned or the bubble result of death is threatened with a maximum sentence of twenty years;

c. If Makar for life is carried out with a plan and results in death, is threatened with capital punishment or imprisonment for a certain period of time of maximum twenty years:

(1) Makar against lives can be carried out with ordinary killings (article 338 KHUP), with a plan (article 340 of the Criminal law book (KUHP), plots against independence can take the form of seizing independence or kidnapping (article 333 of the Criminal law book (KUHP); 
(2) The Makar must be committed to the head of the state and when he is confronted with the head of a friendly country;

(3) Paragraphs 2 and 3 constitute a weight if the offense has the consequences mentioned in paragraph 1 above.

\section{Article 164 of the Criminal law book (KUHP)}

"Whoever knows the conspiracy to commit the crime Article 104, 106, 1-7, 1-8, 113, 115, 124, 187, and 187 bis and while the crime can still be prevented, willfully not notify the judiciary or police or threatened, threatened with imprisonment no longer than one year four months or a maximum fine of three hundred thousand rupiah ".

\section{Article 328 of the Criminal law book (KUHP)}

"Anyone who takes someone away from their residence or place of residence temporarily by forcefully places that person unlawfully under his authority and the authority of another person, or to place him in a miserable state, is threatened with kidnapping with a maximum jail sentence of twelve years".

By taking someone away, the act is an ordinary kidnapping action if the act is aimed at people in general, but if the act is directed at the head of state (president) causing government chaos or disturbance to the government, the act can be related to article 104 of the Criminal law book (KUHP), where the threat of criminal acts becomes heavier, i.e. death penalty or imprisonment for a certain period of time of no more than twenty years.

8. Article 338 of the Criminal law book (KUHP)

"Anyone who deliberately takes the life of another person, is threatened with murder with a maximum imprisonment of fifteen years."

When connected with articles 104, 106, and 107 of the Criminal law book (KUHP) is the murder of the president or vice president can result in weakening the joints of 
government, the government is easy to destroy so that the enemy can easily control the territory of the country. So the emphasis is on the intended subject, if the subject or victim is another person (not the head of state) the criminal threat is a maximum of 15 years, while if the victim is a head of state or president, then the threat of punishment is a death sentence, life, or for it's only twenty years in prison.

9. Article 487 of the Criminal law book (KUHP)

"Prison penalties specified in articles 131, 140 (1), 141, 170, 213, 338, 341, 342, 344, 347, 348, 351, 353, 355, 438, 433,459 and 450 as well as imprisonment for a period of time. certain sentences according to articles 140 (2) (3), 339,340 and 444 can be added by a third if the person who is guilty when committing a crime has not passed five years after serving for the full amount of imprisonment imposed on him, either due to wrong or crime which is explained in those articles, or because of one of the crimes referred to in article 106 of the second and third paragraph of the Criminal law book (KUHP), 107 the second paragraph, as far as the crime committed or the acts that accompany it cause injury or death, article 131 second paragraph and thirdly, 137, 138 of the Criminal law book (KUHP) of the Army, or since the crime was for him completely removed, or if at the time of committing a crime, the authority to carry out the crime has not expired".

This article is usually called 'special recidivist' in the form of recidivists against certain crimes that fall into one group (the same type) regulated in articles 486,487 , and 488 of the Criminal law book (KUHP).

a) Related to article 107 of the Criminal law book (KUHP), namely:

(1) Article 111 BIS

Threatened with a maximum prison sentence of six years:

1. Anyone who establishes relations with a person or entity domiciled outside Indonesia, with the

WALISONGO LAW REVIEW (WALREV) Vol 01 No 1 April 2019 || 63 
intention of moving that person or entity to provide assistance in preparing, expediting or holding a government overthrow or with a view to promising or giving assistance to that person or body in the act, or with a view to preparing to expedite or overthrow a government.

The 2 persons who put an object that can be used to provide material assistance in preparing, expediting, or carrying out the overthrow of government, while it is known there are strong reasons to suspect that the object will be used for these actions.

The 3 people who have an agreement about an object can be used to provide material assistance in order to prepare, expedite, or carry out government overthrow, while there are known reasons to suspect that the object will be used for the act and the object or other object as a substitute, incorporated with such objectives or intended for that purpose by persons or objects domiciled outside Indonesia.

(2) The objects used to commit the crimes mentioned in paragraphs 1 to 2 and 3, or those which are related to those crimes, can be seized.

(3) The link between article 111 BIS and article 107 of the Criminal law book (KUHP) is if someone has committed an act that fulfills the formula or elements contained in article 111 bis and is proven with the intention to overthrow the government, then the perpetrators of the crime can be threatened with article 10 of the Criminal law book (KUHP), where the criminal threat will be more severe than the criminal threat contained in article 111 of the BIS.

From the description about the formulation of Makar crime above, the author sees that the Criminal law book (KUHP) does not provide an exact definition of the term Makar since it was first used in 
article 87, so that the article regarding Makar crime contains unclear formulation and objectives which also results in criminal articles next Makar. The unclear formulation according to the author is the 'rubber article' because there are many theories and opinions expressed by criminal experts about the elements that can be said to be an act of Makar crime, where the formulation is contained in article 87 of the Criminal law book (KUHP) which reads:

"It is said there is a makar to do a deed, if the intention to it has turned out from the commencement of the implementation as referred to in article 53 Criminal law book (KUHP)"

While article 53 of the criminal law book (KUHP) paragraph 1 (Moeljatno 1996:24) reads:

"Trying to commit the crime is sentenced, if the intention of it has turned out from the commencement of execution, and the completion of the implementation is not solely due to its own will."

In the event of this experiment, the criminal law book (KUHP) only provides a form of probation that can be sentenced to action (article 53 criminal law book (KUHP)) and which can't be sentenced to violations-Article 54 criminal law book (KUHP)-(Damapili 2016:3), causing a variety of theories such as described earlier. About the limitations of when one can be said to have an intention to commit crimes and where the constraints between the commencement and implementation itself, the Criminal law book (KUHP) also does not provide clear signposts. Instead of aiming to give the judges the freedom to determine the deeds that can be categorized as experiments with the help of criminal law and public opinion in the community. The criminal law book (KUHP) precisely causes the confusion of the law both on the level of theory and practice. Thus, the criminal law book (KUHP) does not determine its attitude explicitly as to what, how, and when a deed is categorized as a good trial in the form of intention, commencement, and execution is not or unfinished. 
Abidin Farid and Andi Hamzah (2006:7) participated in making proposals against Delic formula in the upcoming national Criminal law book (KUHP), as follows:

"Whoever tries to commit a crime can be punished if his intention has already turned out with the commencement of implementation and that the execution is not completed is due to the leaddown-state that does not take on his own will"

The formulation that this is, at least has explained the intention that is with the beginning of the executor, because evil of any intention without the commencement of execution is not worth anything and still an inner attitude of one. As the desire to steal or take other people's belongings began to be realized, for example, had entered the house or pickpockets had put his hand into the pocket of the person who wanted to pickpocketed. (Marpaung 2008: 95) Not completion of the implementation can still be sentenced because the completion of the implementation is merely caused by circumstances that do not join the will of the crime maker. Unlike other country's criminal offenses that expressly determines its attitude to the finished deed and is not or is not completed. For example, article 25 of the South Korean Criminal law book (KUHP) (Hamzah 1987:60) reads:

"Someone who starts an offense but does not complete it or the result does not occur can be convicted for attempting to commit offense. Criminal for attempted offense can be reduced lower than the completed implementation"

Voluntary termination is governed by article 26 , read as follows:

"If a person of his own will cease his evil deeds at the time he begins and stops before completion, the criminal may be lightened or removed".

According to the sound in article 26 of South Korea's criminal law book (KUHP), that the resignation is voluntary so that the delik is not realized can be the basis of warning or omission of criminal. Unlike the South Korean system, the Japanese criminal law book (KUHP) does not include the third element of the Indonesian model, regulating voluntary termination as the basis of which could relieve 
criminal and not the basis for criminal demission. Article 43 of the Japanese criminal law book (KUHP) (Hamzah 1987:85) reads:

Unlike the Indonesian criminal law book (KUHP), and most other criminal law book (KUHP), the Japanese criminal law book (KUHP) does not regulate the test in the terms of the Code. However, the Japanese criminal law book (KUHP) 44 states that the trial can only be sentenced only if it is specifically determined in each of the relevant chapters. The Japan Criminal law book (KUHP) and the South Korean Criminal law book (KUHP), in accordance with article 53 of the Indonesian Criminal law book (KUHP), do not specify that the crime (maximum) for the pilot can be reduced to a maximum of one third criminal for completion. In other words, the judges are free to determine the amount of time reduction.

The Thai criminal law book (KUHP) also does not include any third element as is the case with the Japanese criminal law book (KUHP) and the South Korean criminal law book (KUHP), but the number is firmly determined. Article 80 of the Thai criminal law book (KUHP) reads as follows:

"Whoever starts committing an offense, but does not finish it or finishes it but does not reach the end of the line trying to do an offense. Whoever tries to commit an offense, is threatened by two-thirds of the penalties specified for the offense"

Thus, if we are in the comparison of the above comparisons, the Indonesian criminal law book (KUHP) tends not to expressly provide the definitions, criteria, and limitations of criminal against the attempted delik perpetrators. It is of course very difficult for the prosecution to prove that not being completed by the makers is merely due to circumstances not dependent on his own. Certainly the general Prosecutor's goods have difficulty proving this third element because it is the core or additional terms can be a maker or by some experts called elements or elements.

While if it is reviewed from the Criminal Policy (Arief 1996:3031 ), the criminal offence is governed in chapters 104, 106, 107, and 108 of the criminal law book (KUHP) and its elements in article 87 
and article 53 of the criminal law book (KUHP) is still very far from what to expect, namely to tackle Crime. In this case, the formulation of crimes that can be pursued is the application of criminal law, which is about criminal acts stipulated in 104, 106, 107, and 108 of the criminal law book (KUHP) where its elements is formulated in article 87 and 53criminal law book (KUHP). Conditions in which a chapter in the criminal law book (KUHP) that creates many theories and interpretations of the reason the criminal law book (KUHP) itself does not explicitly parse it is still very difficult to apply as a form of criminal policy. The reason the criminal law book (KUHP) would be ideal to apply as intended by the legislator if the theory is already a multi-interpretation of its formulation.

Nevertheless, the efforts to counteract crimes through the making of criminal (law) in fact are also an integral part of the social welfare effort. Therefore, it is reasonable that criminal law is an integral part of the social policy. Social policy is a rational effort to achieve the welfare of the community while covering the protection of society. So in the sense of social policy included social Welfare and Social Defense (Arief 1996:32). Makar Criminal act is a legal political product, where the criminal law politics itself is identical to the notion of a crime-seeking policy with criminal law, but the policy does not necessarily have to be sought by the means of penal (law Repressive), should also be addressed with other efforts as a preventive effort (preventive). So in the end the idea that was built was the question of what it happened was no longer merely the law of what was used to tackle the crime

\section{Enforcement of Criminal Crimes Acts in Indonesia Post- Reformation}

Freedom of opinion is the right of every individual since the birth that has been protected by the Constitution, freedom of thought and opinion is governed in the Fourth Amendment of the Constitution of the Republic of Indonesia year 1945 article $28 \mathrm{E}$ paragraph 3 reads : ' Everyone is entitled to 
freedom of union, gathering and issuing opinions '. Independence thinks and argues like a new tap where the people of the mainstream aspirations flows heavily to the desired parties (Syahri tt: 2), where previously, the new Order regime in power is strongly controlling life and Death of information. It ended after Suharto's downturn from power on 21 May 1998 surprisingly the aftermath of the reform movement which was driven by the student movement which later changed direction into a great riot to cause severe damage the building and the deaths of hundreds of people in various major cities in Indonesia (Denny JA 2006:33).

In this case, let us look at some of the jurisprudential crimes of treason in Indonesia, especially those that occurred after the reformation. In 2011, the Wamena District Court tried Obeth Kosay, ToebagaKilungga aka YahyaKilungga, WombiTabuni, Wiki Meaga, Pdt. Ali Yikwa alias Ali Wenda, MekiTabuni for alleged treason set out in Article 106 of the Indonesian Criminal law book (KUHP) Jo. Article 55 paragraph 1 of the Criminal law book (KUHP) whose case is registered in the Wamena District Court Number 38 / Pid.B / 2011 / PN.Wmn (Supreme Court of the Republic of Indonesia, 2017). The Macar element of crime that is to be revealed to the defendants is Makar with the intent that all or part of the state falls into the hands of the enemy or separates some parts of the country from the other. Based on the commencement of the implementation stipulated in article 53 of the criminal law book (KUHP), manifested in the establishment of Team 1000 TPM/OPM led by Dani Tani Tabuni aiming to go to Jakarta meet with the president of Indonesia to ask for independence and separate from Homeland Whose membership reaches 500 people, where each person who registers and submits the photo fitting to be made an ID card, and Dani Tani Tabuni as the TPM/OPM leader ordered the defendant to use the star flag Kejora at the funeral ceremony of one of the TPM/OPM members who had a global world. For the fact of the trial, PN Wamena sentenced the defendant to the defendants with an 8-year jail sentence.

In the year 2013, PN Sorong also prosecutes an Obaja Kemesrar on the accusation of evil investigation to commit criminal offence registered number: 114/Pid. B/2013/PN. SRG (Supreme Court of INDONESIA, 2017). The case began during the merger of the defendant to the independent 
Papuan Organization (OPM) and also joined the independent Papua organization of the West Papua National Liberation Army (OPM-TPN). On May 01, 2013, together with his partner, the preparation for Mama's Party was held. Mama's party is a password for defining events of the Morning Star flag raising and Dawn star as well as proclaiming the independence of the Republic of West Papua. Based on the commencement of the implementation, Obaja Kemesrar was sentenced to article 110 paragraph (1) of the criminal law book (KUHP) of article 106 of Criminal law book (KUHP) with imprisonment for 1 (one) year and 6 (six) months.

Not to stop there, in 2012 the Supreme Court on the level of cassation examined the criminal case for the defendant Salamin alias Ahmad Mujahid bin Ahmad Basar, Mujono Agus Salim alias Nurdin on charges of evil investigations to commit criminal acts of the Macar Registered at number $961 \mathrm{~K} / \mathrm{Pid} / 2012$ (Mahmakah Agung 2017). The case was started on May 23rd, 2011 when the investigation was conducted at the House of Jl. Nusa Indah No. 3 Rt. 04 in Genuk Village, Ungaran West District,Ssemarang Regency by Polda Jateng and apparently occupied by suspected perpetrators of criminal acts of Macar To overthrow the NKRI by establishing the Islamic State of Indonesia (NII). From the investigation, is foreclosure of the evidence in the form of 1 (one) unit of car Honda CRV, 1 (one) unit of car Daihatsu XENIA, 1 (one) unit motorcycle Suzuki Spin 125 cc, 1 (one) unit of motorcycle Win, 11 (eleven) Giant brand bikes. From the search was found a number of documents that the defendant I entered became a member of the NII in 1990 and was dibaiat by Imam Panji Gumilang with the purpose of founding the Islamic State of Indonesia. In 2005, the defendant I was appointed as the Coordinator of the chief Financial Department of Central Java province, and other supporting documents.

Considering the application of casation No. 05/Akta. Pid/2012/PN. Ung and based on the fact of the trial, the Tribunal rejected the appeal of the applicant and sentenced them to criminal imprisonment for 6 years respectively. The Macar crime case also occurred in the year 2016, but this time is not the same as the Macar crime that the writer has described above. In the case of a criminal offence at the District Court of Wamena, the Sorong 
District Court, and the Makar criminal act in the Supreme Court at the rate of cassation is a complete criminal act and a permanent legal force, unlike the Makar crime that occurred in the year 2016 that since the introduction on 2 December 2016 until now the criminal case is not met the point of light.

This case commenced at the time of the 2016 Jakarta regional election, where Basuki Thajaha Purnama who is a candidate for Incamben was set as suspected blasphemy by the South Jakarta District Court. The religious blasphemy case invites a great reaction from Muslims to the implementation of the 212 demonstration wave (2 December 2016). The aftermath of the action was the arrest of 11 activists on December 2 at 03.00 to 06.0o WIB at different locations on charges of conducting the Makar settlement. The eleventh suspect seven of them are not related to Article 107 of Junto 110 Criminal law book (KUHP), they are Kivlan Zein, Adityawarman, Ratna Serumpet, Firza Husein, Eko Suryo Santjojo, Alvin Indra, and Rahmawati Sukarno Putri. While the other 3 are linked with the ITE ACT of article 107, the three are Sri Bintang Pamungkas, Jamran, and Rizal (Republika 3 January 2017). The suspects allegedly tried to exploit and provoke time to occupy the DPR building, and urged the MPR special to revoke the MPR's mandate from President Joko Widodo (Republika 3 January 2017).

Almost 1 year ago, this case is not completed even in the level of investigation and status of $\mathrm{P} 18$ or the completeness stage of the evidence tool. It is not clear that this certainly gives red results to law enforcement in Indonesia. We should suspect that there must be something wrong from his home in the Criminal law book (KUHP), the enforcement of the law, or the intervention of the ruler is strong enough. Judging from its formulation, it is clear that the formulation of criminal acts in the criminal law book (KUHP) is still multi-interpretation and contains the lack of formulation and objectives as described in the preceding subsection. Judging from its law enforcement and ruling intervention, it is clear that this criminal offence is a political product that becomes a weapon for the ruler to secure his power in both the protection of the State and to protect and policy of arbitrary rulers. 
Looking at the jurisprudence record above, we can see a very clear difference to the three court decisions, namely the ruling of PN Wamena, the ruling of the Sorong PN, and the ruling of the Supreme Court appeal, as well as 2 cases of subsequent Makar acts Arrest of 11 activists ahead of the 212 peace ADSI and arrest of 5 activists ahead of the Rally Act 313 on March 31,2017 . The first three jurisprudence records are the complete criminal act and the Permanent legal force in which the its verdict is based on the evidence and the commencement of clear implementation as stipulated in article 53 of the criminal law book (KUHP). The defendants in the criminal case registered in PN Wamena No. 38/Pid. B/2011/PN. Wmn were sentenced to jail criminal respectively 8 years based on the commencement of implementation manifested in the formation of the 1000 TPM/OPM TEAM led by Dani Tani Tabuni who aims to go to Jakarta met with the president of INDONESIA to ask for independence and separated from the NKRI whose membership reaches 500 people, where everyone who registers and hands over the photo fitting to be made a card sign The identifier and Dany Tabuni as chairman of the TPM/OPM ordered the defendant to use the Morning Star flag at the funeral ceremony of one of the TPM/OPM members who were in a global world.

Nevertheless, the three criminal cases still pose fundamental legal issues, even though they have remained legal force. This is because the Criminal law book (KUHP) is not firmly expressed in its formulation. According to the author, it could be the interpretation of Makar crime is returned in the real translation of the word Aanslag in Dutch, so that in the jurisprudence note is not encountered an element of attack at all. More than that, the ruling on the three cases is very dangerous for development, because it has no clarity (lex certa terms), especially in the Criminal law book (KUHP) (Vedic 2016:9). For criminal matters registered in PN Sorong number $114 /$ Pid. B/2013/PN. The SRG, the defendant was sentenced to imprisonment for 1 year 6 months based on the commencement of implementation in the merger of the defendant to the free Papua Organization (OPM) and also joined the free Papua organization Liberation Army National West Papua (OPM-TPN). On May 01, 2013, together with his partner, the preparation for Mama's Party was held. Mama's party is a password to define event events of the Bintang Kejora or Morning Star as 
well as proclaiming the independence of the Republic of West Papua. Criminal matters at the level of cassation that are registered in the Supreme Court No. $961 \mathrm{~K} / \mathrm{Pid} / 2012$, the Tribunal rejected the appeal and remained criminal to the defendants with imprisonment for 6 years respectively based on the A search in the house of defendants explaining that the defendant belongs to the organization of the Islamic State of Indonesia (NII) and has been dibai'at by Imam Panji Gumilang with the purpose of founding the Islamic State of Indonesia.

This is in disagreement with the arrest of activists ahead of the action of 2 December 2016 (Peace Act 212) and demonstration of 31 March 2017 (Demonstration action 313) in which the suspects were meshed with criminal offences committing a makar crime set In article 110 KUHP junto Article 104 criminal law book (KUHP), on the basis of the alleged attempt to exploit and provoke the period to occupy the HOUSE and then urged the MPR special session to revoke the MPR commission from President Joko Widodo. But ironically both arrests against activists 212 and 313 the case just stopped at the level of investigation. It is indicated that police are difficult to reveal the evidence of preliminary execution against the criminal offense. This certainly gives the impression that the arrest for the sake of political crimes, where law enforcement is eager to protect the regime in power. In addition, the leniency of interpretation of the treason criminal articles in the Criminal law book (KUHP), namely in the absence of a definition of treason crime along with its parameters in the form of intentions and commencement of implementation.

\section{Formulation of Criminal Crimes in Renewing Criminal Law}

In a juridical perspective, the deed is a very dangerous deed for the sovereignty of the State, the national integrity proclaimed as the unity and lofty ideals of being a sovereign nation can be lost. Therefore, disruptions to state security must be resolved in ways that are humanized, while still upholding the fundamental rights of citizens (Permana, 2016:4). In an effort to cope with these disorders, the Criminal law book (KUHP) provides the 
signs contained in book II of KUHP, namely chapters 104, 106, 107, and 108 of criminal offence. However, the Macar crime formulation still contains many problems that need to be evaluated in order to realize the ideals as a sovereign nation.

The main problem is that the Criminal law book (KUHP) does not define what is called Makar, and when one can be said to do Makar action. The parameters given by KUHP in defining the Makar are still very abstract, giving rise to many interpretations of legal experts. The parameters provided by KUHP in the form of intention and commencement of implementation as stipulated in article 53 of KUHP, but the intention and commencement of the implementation of what is required by KUHP is not also explained, although in this case the experts have expressed his theories on intentions and commencement. This directs the authors 'identification that the Makar crime formulation set in KUHP contains two very basic problems. First, that in formulating Makar criminal acts, KUHP does not provide a definition of what is meant by Makar. Secondly, the Makar crime elements stipulated in chapters 87 and 53 of KUHP in the form of intention and commencement of implementation are also not given a clear limitation, when one is said to have an intention to commit criminal acts of makar and when a person is stated to have begun committing criminal acts, as well as how the boundary between the commencement and implementation is said to be complete.

This condition is certainly harmful to the state system, and endangers the constitutional rights of citizens in expressing opinions and minds including criticism of the ruler and endangering the sovereignty of the State. The unclear formula will give the ruler an opportunity to abuse the criminal offence clauses to secure his authority. The indications are seen in the subchapter of the enforcement of makar criminal acts in Indonesia after reform by looking at the jurisprudence records. The cases of arrest of activists ahead of the demonstration Act of 212 and 313 are evidence of indications of such abuses. The arrest was only based on allegations that there was an effort to exploit and provoke the time to occupy the DPR and force the Special assembly of the MPR to revoke the MPR's mandate from President Joko Widodo. This is evidenced by the prey on this case and stops at the level of 
investigation due to police difficult to prove the allegations due to lack of evidence tools.

This situation is certainly very alarming, and very urgent to be done in the immediate renewal of criminal law, especially related to criminal offence in the case of criminal policy. KUHP must firmly determine its attitude in terms of defining the term Makar and give the parameters of intent and commencement of implementation.

It departs from the term Aanslag (Dutch) which means attack or aanval which means offensive with no good intentions (Chazami 2002:7), while according to the Indonesian language, the English translates as bad sense, deception, and deeds With the intention of killing people (Government of Indonesia tt: 618). The attack as a translation of the word Aanslag in KBBI is interpreted as "come to fight, injure, and fight, and so on" (KBBI tt: 881). While the interpretation in KUHP through article 87 which reads:

"There is a Makar if the intention to it has turned out from the commencement of the implementation as mentioned in article 53 of the Criminal law book (KUHP)" (Moeljatno, 1996:36). The author assesses this interpretation is not an interpretation of the term Makar itself but the element it can say for a person to do makar.

Judging by the dangers of the Makar criminal act which can eliminate the state's sovereignty, the author further agrees with the definition expressed by P.A. F Lamintang, who said that the word Aanslag should not necessarily be interpreted as a Acts of violence, because the formulation stipulated in article 106 of KUHP is actually any action taken to harm the interests of the state law in the form of entirety State territory. If Makar is only interpreted as an assault, then without attack, the deed cannot be said as criminal offence (Vedic 2016: 9).

The academic manuscript draft of KUHP (Government of Indonesia 2015: 212) is said that the criminal act of the country's security is a delic resulting in the occurrence of the community or disruption of political stability and Security. KUHP of the Police law division said that Makar is the intention to do a deed that has been realized with the commencement of the implementation of the deed (Polri 2015: 35). Burhanuddin Ali Ahmadi stated that Makar is a resistance to legitimate government with the intent to 
overthrow the government or oppose the wisdom that has become a statute by resisting the law, either through with power Other forces or in any other way (Dictico 15 Oct 2016).

With this term makar, attributed to a clear definition and not a definition that directly describes the term Makar itself, then the criminal law book (KUHP) looks more firmly stated its attitude in determining what is meant by criminal acts of Makar. Based on the definitions expressed by experts, the authors can conclude that the Makar is an act against the law that is done to harm the legal interests of the State in the form of entirety state both with the power of weapons and with power Other. With this definition, it can be clearly differentiated between a real threat to a country with activities that are academic in the form of criticism of the ruling policy as well as in other forms.

After defining what is Makar, KUHP must also define the elements of criminal acts itself in the form of intention and commencement of implementation. In this case, there have been many theories of jurists explaining the intent and commencement of the implementation. About the intention that is an element of the experiment, Prodjodikoro (2000: 55) defines that the word experiment means an attempt to achieve a goal that is ultimately not or unattained. The majority of scholars argue that intentions can be likened to deliberate in all levels, but Moeljatno (Prakoso 1996: 60) suggests the opposite:

1) Intention do not be likened to deliberate, but the potential of the can change to become intentional when it has been shown to be a intended deed. In this case all the deeds necessary for the crime are already needed but the consequences do not arise (the experiment did not finish/Voltooide poging), there is the same intention as when facing the completed proceeding.

2) If it has not been shown in deed, then the intention still is the inner attitude that gives direction in deed.

3) Because the intention is not equal and cannot be confused with the intent, then the content of the intention do not be confused with the content of intentional when the crime arises, for it needs to be proved by 
itself that certain content has also had an intention not yet shown Be an act.

Similarly to the definition of Makar, KUHP reserves the right to choose which theory to use to define intent; it is nothing but the aim of making legal certainty and formulation in KUHP. About this intention, the author can conclude that the intention is the inner attitude of one who gives direction in deed, when the intention has been demonstrated then the potential intention to be deliberate. Moving on to the beginning of the implementation which is the second element in criminal acts of Makar, this element is the most difficult element to distinguish between the commencement of implementation and preparation. On this matter there are many differences of opinion among scholars, but once again KUHP has the right to choose which theory will be used in the renewal of criminal law in the future.

Simons argues as follows: 1) at the formal proceeding, the deed of execution is when the deed is initiated in the formal formula; 2) at the Proceeding Materiel, the act of execution is when it has been initiated or executed/done by its nature directly can lead to the consequences prohibited by law without requiring any other deeds. In book I part proceeding trial, article 18 of the Criminal law book (KUHP) of the bill mentions that:

1) Attempts to commit a criminal offence, if the author has begun to perform the commencement of the criminal act, but the implementation does not finish or does not achieve the result or does not cause a banned, not because Solely upon his own will.

2) Commencement of implementation as intended in paragraph 1 occurs if;

a) The act is intended for criminal acts.

b) Actions performed directly close to or potentially cause a criminal offence to be addressed.

c) The makers have committed the act against the law.

By including the definition and start of implementation in the criminal law book (KUHP) as stated in the Criminal law book (KUHP) 2015 this year, 
it will be a similarity of interpretation about the commencement of this implementation so as to create a legal certainty.

\section{Conclusion}

1. Be reviewed from criminal policy, then a criminal offence stipulated in sections 104, 106, 107, and 108 of the criminal law book (KUHP) and its elements contained in article 87 and article 53 of the Criminal law book (KUHP) is still very far from what is expected to tackle crimes In particular with regard to State sovereignty. This is because the criminal law book (KUHP) does not provide a definition of what is meant by criminal acts, nor does it provide clear parameters of criminal offence elements in the form of intention and commencement of implementation.

2. The infidelity of the Criminal law book (KUHP) in defining Makar criminal acts along with this its elements raises various theories and interpretations so that it is prone to be abused by the authorities to protect its power and threaten the constitutional rights of citizens The country stipulated in article 28 of constitution 1945.

In the era of reform marked with independence thinking and argue and convey it both with oral and written, the position of the formulation of no criminal Makar in the Criminal law book (KUHP) is puzzled even becomes a dilemma'. On the one hand, the Makar criminal offence is needed to keep the sovereignty of the country but on the other hand its undefined presence threatens the independence of the constitutional rights of citizens.

Note that existing jurisprudence contains problems despite fixed legal force, namely; Because the criminal law book (KUHP) is not firmly expressed in the formulation, it could be that the interpretation of criminal acts is returned in the actual translation of the word Aanslag in the Dutch language, which means an attack, then in Jurisprudence notes on the encountered element of attack at all.

3. The fundamental problem in the criminal offence formulation in the criminal law book (KUHP) is that the Criminal law book (KUHP) itself does not define what is meant by criminal acts and does not give clear 
Eman Sulaeman, Crime of Makar and Its Enforcement in Post Reform...

parameters to its elements. Therefore, the Criminal law book (KUHP) of laws should take a decisive stance on the definition of criminal offence along with the its elements in which the legal political arrangements are aligned with the principles of the State of law and Democracy and uphold the constitutional rights of citizens governed by article 28 of the Constitution of the Republic of Indonesia. [w] 


\section{Noted}

Criminal politics (Criminal policy) has three meanings, namely: a) in a narrow sense, the overall principles and methods underlying and the reaction to violations of criminal law; b) in the broad sense, the entire function of the law enforcement officers, including the workings of the courts and the police; c) In the most widespread sense, the overall policy is carried out through the legislation of the invitation $\neg$ and official bodies, aiming to enforce the center norms of society.

Crime prevention can be taken in 3 ways, namely: a) the application of criminal law application; b) noncriminal Prevention (prevention without punishment); c) to affect the public view of crime and EAS through the mass media (influencing views of society on Crime and Punishment/mass media). 


\section{BIBLIOGRAPHY}

Abdurisfa, Adzan Trahjurendra. tt. Politik Pengaturan Tindak Pidana Makar di Indonesia. Makalah. Malang: Fakultas Hukum Universitas Brawijaya.

Ali, Ahmadi Burhanuddin. 2016. "Apakah yang Dimaksud Dengan Makar Menurut Hukum Indonesia”, dalam Diktio.id. diakses 15 Oktober.

Amanda, Agustin Rio. 2013. "Tindak Pidana Terhadap Keamanan Negara Dalam Perspektif Delik Politik.” Jurnal MWH 40 (3): 344-348.

Arief, Barda Nawawi. 1996. Bunga Rampai Kebijakan Hukum Pidana. Bandung, Citra Aditya.

Badan Pembinaan Hukum Nasional Kementerian Hukum dan Hak Asasi Manusia Republik Indonesia. 2015. Draft Naskah Akademik Rancangan Undang-undang Tentang Kitab Undang-undang Hukum Pidana (KUHP). Jakarta: BPHN.

Chazami, Adam. 2002. Kejahatan Terhadap Keamanan dan Keselamatan Negara. Jakarta: PT Raja Grafindo Persada.

Damapili, Dedi Ksatria. 2016. "Percobaan Melakukan Kejahatan Menurut Pasal 53 Kitab Undang-undang Hukum Pidana”, Jurnal Lex Privatum, 4 (2): 82-91.

Departemen Pendidikan dan Kebudayaan. 1989. Kamus Besar Bahasa Indonesia. Jakarta: Balai Pustaka.

Dharma, Weda Made. 2016. Tindak Pidana Makar dalam Rancangan KUHP. Jakarta: Aliansi Nosional Reformasi KUHP.

Direktori Putusan Mahkamah Agung Republik Indonesia (putusan.mahkamahagung.go.id)

Divisi Hukum Polri. 2015. Rancangan Undang-undang Tentang Kitab Undang-undang Hukum Pidana (KUHP), Jakarta.

Djoko, Prakoso. 1986. Tindak Pidana Makar Menurut KUHP. Jakarta: Ghalia Indonesia. 
Engelbrecht. 1960. Kitab Undang-undang dan Peraturan-peraturan Republik Indonesia. Jakarta: PT Soeroengan.

Esthi, Maharan, 2016. "Polisi Tangkap Aktivis Makar," dalam Republika diakses, 2 December.

Farid, Abidin dan Andi Hamzah. 2006. Bentuk-bentuk Khusus Perwujudan (Delik Percobaan, Penyertaan, dan Gabungan Delik) dan Hukum Penitensier. Jakarta: PT Rajagrafindo Persada.

Hamzah, Andi. 1987. KUHP Korea Sebagai Perbandingan. Jakarta: Graha Indonesia.

J.A Denny. 2006. Jatuhnya Soeharto dan Transisi Demokrasi Indonesia. Yogyakarta: LKIS.

Lamintang, P.A.F. 1987. Delik-delik Khusus Kejahatan-kejahatan Terhadap Kepentingan Hukum Negara. Bandung: Sinar Baru.

Lampost.co

Leden, Marpaung. 2008. Asas-Teori-Praktik Hukum Pidana. Jakarta: Sinar Grafika.

Majelis Permusyawaratan Rakyat Republik Indonesia, Undang-undang Dasar Negara Republik Indonesia Tahun 1945. Jakarta: Sekertariat MPR RI

Marpaung. 1991. Unsur-unsur Perbuatan yang Dapat Dihukum. Jakarta: Sinar Geofisika.

Metrotvnews.com

Moeljatno. 1996. Kitab Undang-undang Hukum Pidana (KUHP). Jakarta: Bumi Aksara.

Permana, Fauzah Hamzah. 2016. "Kebijakan Hukum Pidana dalam Penanggulangan Tindak Pidana Makar di Indonesia." Diponegoro Law Jurnal 5 (4): 1-11

Pipin, Syarifin. 2000. Hukum Pidana di Indonesia. Bandung: Pustaka Setiam. 
Prodjodikoro, Wirjono. 2008. Tindak-Tindak Pidana Tertentu di Indonesia. Bandung; PT Rafika Aditama.

Pusat Bahasa Departemen Pendidikan Nasional. 2008. Kamus Besar Bahasa Indonesia. Jakarta: Pusat Bahasa.

Republika,co.id.

Rio, Armanda Agustian, tt. "Tindak Pidana Terhadap Keamanan Negara Dalam Perspektif Politik.” Makalah. Bangka Belitung: Fakultas Hukum dan Sosial Universitas Bangka Belitung.

Sudarto. 1986. Hukum dan Hukum Pidana. Bandung: Alumni.

Suryani, Widyati Lidya. 2016. "Tindak Pidana Makar". Majalah Info Hukum Singkat, 8 (2).

Syafrudin, Syahri Ahmad. tt. Kebebasan Berpendapat Melahi Media Baru Dalam Bayang-Bayang UU Informasi dan Transaksi Elektronik (ITE). Jakarta: Akademi Komunikasi Bina Sarana Informatika. 
Eman Sulaeman, Crime of Makar and Its Enforcement in Post Reform...

WALISONGO LAW REVIEW (WALREV) Vol 01 No 1 April 2019 || 84 